\title{
Tumor Suppressor p53-Binding Protein 1
}

National Cancer Institute

\section{Source}

National Cancer Institute. Tumor Suppressor p53-Binding Protein 1. NCI Thesaurus.

Code C88927.

Tumor suppressor p53-binding protein 1 (1972 aa, $214 \mathrm{kDa}$ ) is encoded by the human TP53BP1 gene. This protein may play a role in nonhomologous end joining DNA repair. 